\title{
Transmission Electron Microscopy of Interfaces in Joints between Pb-Free Solders and Electroless Ni-P*1
}

\author{
Naoki Torazawa ${ }^{1 * 2}$, Shigeo Arai ${ }^{2}$, Yoshihisa Takase ${ }^{3}$, Katsuhiro Sasaki $^{1}$ and Hiroyasu Saka ${ }^{1}$ \\ ${ }^{1}$ Department of Quantum Engineering, Nagoya University, Nagoya 464-8603, Japan \\ ${ }^{2}$ Center for Integrated Research in Science and Technology, Nagoya University, Nagoya 464-8603, Japan \\ ${ }^{3}$ Corporate Components Development Center, Matsushita Electronic Components Co., Ltd., Osaka 571-8506, Japan
}

\begin{abstract}
Microstructures of joints between a Ni-8 mass\%P UBM (under bump metallization) and three different Pb-free solders, i.e., Sn-Ag, Sn$\mathrm{Ag}-\mathrm{Cu}$ and $\mathrm{Sn}-\mathrm{Ag}-\mathrm{Cu}-\mathrm{Bi}$ were studied by transmission electron microscopy. The phases formed near the joint interfaces as well as inside the solders during soldering were identified on the basis of electron diffraction and EDX analysis without ambiguity. In the Ni-P under bump metallization near the interface with the solders, P-denuded Ni-20 mass\% P layer was observed, where a high density of columnar voids were formed. Also, in $\mathrm{Ni}(\mathrm{Cu}) \mathrm{SnP}$ intermetallic, which is adjacent to the P-denuded Ni-20 mass\% $\mathrm{P}$, a high density of spherical voids were observed. These voids degrade the joint strength. Change of the above microstructures during thermal cycling between $253 \mathrm{~K}$ and $453 \mathrm{~K}$ was also observed.
\end{abstract}

(Received November 7, 2002; Accepted May 2, 2003)

Keywords: tin-silver solder, tin-silver-copper solder, tin-silver-copper-bismuth solder, electroless nickel-phoshor, transmission electron microscopy, semiconductor package, focused-ion beam, void, strength, fracture, thermal cycling

\section{Introduction}

Recently $\mathrm{Pb}$ free solders have attracted much attention as substitutes for the conventional $\mathrm{Pb}-\mathrm{Sn}$ eutectic solders in order to cope with environmental issues. ${ }^{1)}$ The microstructure of solders joints has been studied mostly using scanning electron microscopy (SEM), ${ }^{2)}$ the spatial resolution of which is low. Transmission electron microscopy (TEM) provides a higher spatial resolution to observe the structure of the layers in a solder joint directly. Although TEM observation is a very powerful tool, it is only very recently that analysis of solder joints using TEM was carried out. One of the obvious reason for this is that preparation of a thin foil specimen of a solder joint for TEM analysis is extremely difficult with the conventional technique available hitherto, because the joint includes materials with low-melting points. However, recently a novel technique, a focused ion beam (FIB) technique, has been successfully applied to preparing a TEM foil specimen of a solder joint. ${ }^{3-6)}$ Matsuki, Ibuka and $\mathrm{Saka}^{6}{ }^{6}$ carried out a comprehensive analysis on the microstructure of $\mathrm{Pb}-\mathrm{Sn}$ eutectic solder joints. More recently TEM observations of $\mathrm{Pb}$-free solders have been carried out by Kariya et al. ${ }^{7)}$ However, their observations did not clarify the detailed structure of the solder joints. The aim of the present study is to identify, by a comprehensive TEM observations, the layers of alloys formed at joints between different $\mathrm{Pb}$-free solders and an electroless Ni-P under bump metallization
(UBM) on a $\mathrm{Cu}$ interconnect in a plastic ball grid array (BGA) package. Microstructures changes during thermal cycling between 253 and $453 \mathrm{~K}$ was also observed to provide information on changes of microstructure in storage and/or field service.

\section{Experimental Procedures}

Samples were prepared from a device package on a printed circuit board for an interposer. Three different types of solders, i.e., $\mathrm{Sn}-\mathrm{Ag}, \mathrm{Sn}-\mathrm{Ag}-\mathrm{Cu}$ and $\mathrm{Sn}-\mathrm{Ag}-\mathrm{Cu}-\mathrm{Bi}$, were used. These chemical compositions are summarized in Table 1. As shown in Fig. 1, the under bump metallizations (UBM) are composed of a $\mathrm{Cu}$ land, $5 \mu \mathrm{m}$ thick Ni-8 mass $\% \mathrm{P}$ and nominally $50 \mathrm{~nm}$ thick $\mathrm{Au}$ films. The $\mathrm{Cu}$ and $\mathrm{Ni}-$ 8 mass $\%$ P films were plated by electroless deposition, and the $\mathrm{Au}$ film formed by substitution plating. The temperature profile for the soldering process is shown in Fig. 2.

Thin foil specimens for TEM observation were prepared using a focused ion beam (FIB) apparatus (Hitachi FB-2000). TEM observations were carried out in two microscopes, i.e., a Hitachi 9000NAR and a Hitachi H-1250ST, at accelerating voltages of $300 \mathrm{kV}$ and $1000 \mathrm{kV}$, respectively. Elemental analysis was also carried out using energy dispersive $\mathrm{X}$-ray (EDX) analysis using an electron beam probe of the diameter of $5 \mathrm{~nm}$.

The intermetallic compounds which are likely to be

Table 1 Samples used in this study.

\begin{tabular}{ll}
\hline $\mathrm{Sn}-\mathrm{Ag}$ & $\mathrm{Sn}-3.5$ mass $\% \mathrm{Ag} / \mathrm{Ni}-8 \mathrm{mass} \% \mathrm{P}$ \\
$\mathrm{Sn}-\mathrm{Ag}-\mathrm{Cu}$ & Sn-3.5 mass\%Ag-0.75 mass\%Cu/Ni-8 mass\%P \\
$\mathrm{Sn}-\mathrm{Ag}-\mathrm{Cu}-\mathrm{Bi}$ & Sn-3.5 mass\%Ag-0.75 mass\%Cu-3.0 mass\%Bi/Ni-8 mass\%P \\
\hline
\end{tabular}

\footnotetext{
${ }^{* 1}$ This Paper was Originally Published in J. Japan Inst. Metals, 66 (2002)

47-52, and 66 (2002) 1122-1130.

${ }^{* 2}$ Graduate student, Nagoya University.
} 


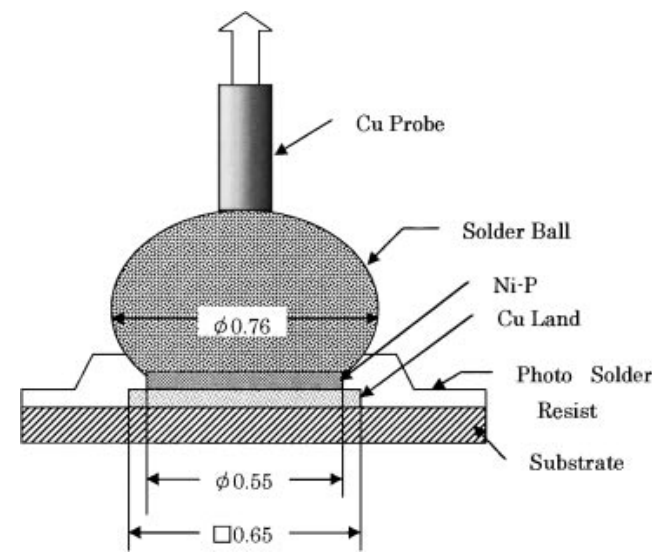

Fig. 1 Schematic illustration of the cross section of a solder/UBM joint. The mechanism of the pull test is also shown.

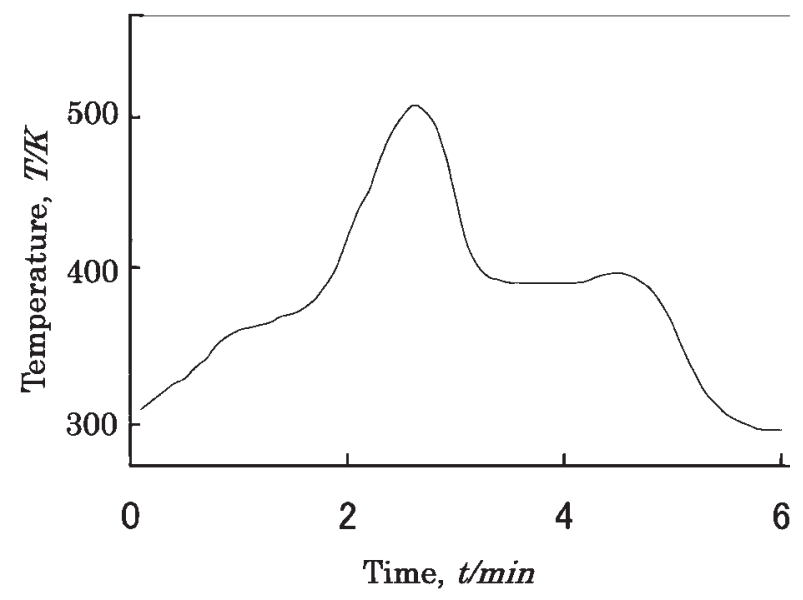

Fig. 2 The temperature profile for the soldering process.

formed in a solder joint are summarized in Table 2, together with $\beta$-Sn. As can be seen from Table 2, most of these compounds have large lattice parameters and complex crystal structures. This often makes it impossible to identify the crystal structure from a single electron diffraction pattern. Therefore, diffraction patterns along different incident electron beam orientations were taken to identify the crystal structure without ambiguity. A relatively wide area, approximately $15 \mu \mathrm{m}$ wide, was thinned in order to reduce noises from the surrounding areas for EDX analysis.

Some of the $\mathrm{Sn}-\mathrm{Ag}-\mathrm{Cu}-\mathrm{Bi}$ solder joints were subjected to thermal cycles between $253 \mathrm{~K}$ and $453 \mathrm{~K}$ up to a maximum of
250 cycles, and the bond strength measured by a pull test using a bond tester PC2400. Here, a $\phi 0.3 \mathrm{~mm} \mathrm{Cu}$ rod was held with a jig just on top of a solder ball to be examined, and then the jig is heated at $563 \mathrm{~K}$. When the solder ball melted, the $\mathrm{Cu}$ rod fell into the molten solder ball and joins. Then, the jig was cooled to $322 \mathrm{~K}$ by air, the $\mathrm{Cu}$ rod was pulled out and the load at which the joint was fractured was defined as its pull load. For each cycle, 10 samples were examined to measure the pull load. The microstructures were examined by TEM.

\section{Results and Discussion}

\subsection{Microstructure and EDX analysis \\ 3.1.1 As-joined structure ( $\mathrm{Sn}-\mathrm{Ag} / \mathrm{Ni}-\mathrm{P})$}

Figures 3(a) and (b) shows a microstructure of solder joint of $\mathrm{Sn}-\mathrm{Ag} / \mathrm{Ni}-\mathrm{P}$ to $\mathrm{UBM}$, at a low magnification, and concentration profiles of $\mathrm{Sn}, \mathrm{Ni}, \mathrm{Ag}$ and $\mathrm{P}$, obtained at points 1-9 by EDX analysis, across the joint, respectively. Figure 3(c) shows the joint at a higher magnification. Au was not detected at any point by EDX elemental analysis. This indicates that $\mathrm{Au}$, which had sat on top of the Ni-P layer before soldering, diffused into the solder and/or Ni-P layer during the mounting of a solder ball. As can be seen from Fig. 3(b), it was confirmed that at least 6 different regions were present, i.e., $\mathrm{Ni}-8$ mass $\% \mathrm{P}$ (points 1 and 2), Ni-20 mass\%P (point 3), a region composed of $\mathrm{Ni}, \mathrm{Sn}$ and $\mathrm{P}$ (hereafter refereed to as $\mathrm{Ni}-\mathrm{Sn}-\mathrm{P}$ ) (point 4), a region composed of $\mathrm{Ni}$ and $\mathrm{Sn}$ (hereafter referred to as $\mathrm{Ni}-\mathrm{Sn}$ ) (points 5, 6 and 7), region composed of $\mathrm{Ag}$ and $\mathrm{Sn}$ (hereafter referred to as $\mathrm{Ag}-$ Sn) (point 8) and Sn (point 9). A high density of columnar voids and spherical voids are present in $\mathrm{Ni}-20$ mass $\% \mathrm{P}$ and $\mathrm{Ni}-\mathrm{Sn}-\mathrm{P}$, respectively. These voids are quite similar to voids formed at a solder joint between $\mathrm{Ni}-8$ mass $\% \mathrm{P}$ and the $\mathrm{Pb}-\mathrm{Sn}$ eutectic solder., ${ }^{4,6)}$

\subsubsection{As-joined structure ( $\mathrm{Sn}-\mathrm{Ag}-\mathrm{Cu} / \mathrm{Ni}-\mathrm{P})$}

Figures 4(a) and (b) shows a solder joint of $\mathrm{Sn}-\mathrm{Ag}-\mathrm{Cu} / \mathrm{Ni}-$ $\mathrm{P}$, at a low magnification, and concentration profiles of $\mathrm{P}, \mathrm{Ni}$, $\mathrm{Cu}, \mathrm{Ag}$ and $\mathrm{Sn}$, obtained at points $1-12$ by EDX analysis, across the joint, respectively. Figure 4(c) shows the joint at a higher magnification. In addition to $\mathrm{Ni}-8$ mass $\% \mathrm{P}$ (points 1,2 and 3), Ni-20 mass\% (point 4) and $\mathrm{Sn}$ (points 10 and 11), which were formed in the $\mathrm{Sn}-\mathrm{Ag} / \mathrm{Ni}-\mathrm{P}$ joint, $\mathrm{Ni}-\mathrm{Sn}-\mathrm{Cu}-\mathrm{P}$ (point 5), $\mathrm{Cu}-\mathrm{Ni}-\mathrm{Sn}$ (points 6, 7, 8 and 9) and $\mathrm{Cu}-\mathrm{Sn}$ (point 12) were confirmed to be present. In $\mathrm{Cu}-\mathrm{Sn}-\mathrm{Ni}$ layer, the concentration of $\mathrm{Sn}$ increases with the distance from the Ni-P substrate. Again, a high density of columnar and spherical

Table 2 Intermetallic compounds likely to be formed at a solder/Ni-P interface.

\begin{tabular}{cccc}
\hline Phase & Bravais Lattice & Space group & Lattice parameters (nm, degree) \\
\hline$\beta-\mathrm{Sn}$ & tetragonal & $\mathrm{I} 41 /$ amd(141) & $a=0.5831, c=0.318$ \\
$\mathrm{Ni}_{3} \mathrm{P}$ & tetragonal & $\mathrm{I}-4(82)$ & $a=0.8952, c=0.4388$ \\
$\mathrm{Ni}_{2} \mathrm{SnP}$ & orthorhombic & $\operatorname{Pmma}(62)$ & $a=1.282, b=0.3594, c=0.50896$ \\
$\mathrm{Ni}_{3} \mathrm{Sn}_{4}$ & monoclinic & $C 2 / m(12)$ & $a=1.2290, b=0.4054, c=0.517, \boldsymbol{B}=103.9^{\circ}$ \\
$\mathrm{Ni}_{3} \mathrm{Sn}_{2}$ & hexagonal & $P 63 / \operatorname{mmc}(194)$ & $a=0.407, c=0.515$ \\
$\mathrm{Ni}_{48} \mathrm{Sn}_{52}$ & orthorhombic & $\operatorname{Pbam}(55)$ & $a=2.445, b=0.520, c=0.409$ \\
$\eta-\mathrm{Cu}_{6} \mathrm{Sn}_{5}$ & hexagonal & $P 63 / \operatorname{mmc}(194)$ & $a=0.42062, c=0.50974$ \\
$\mathrm{Ag}_{3} \mathrm{Sn}$ & orthorhombic & $P \operatorname{Pmn}(59)$ & $a=0.5968, b=0.47802, c=0.51843$ \\
\hline
\end{tabular}



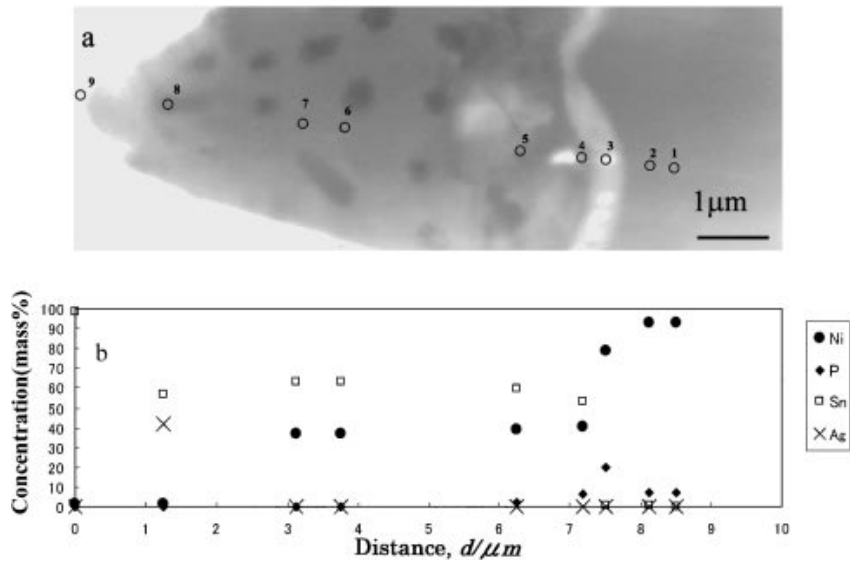
(c) High-magnification TEM of the joint.
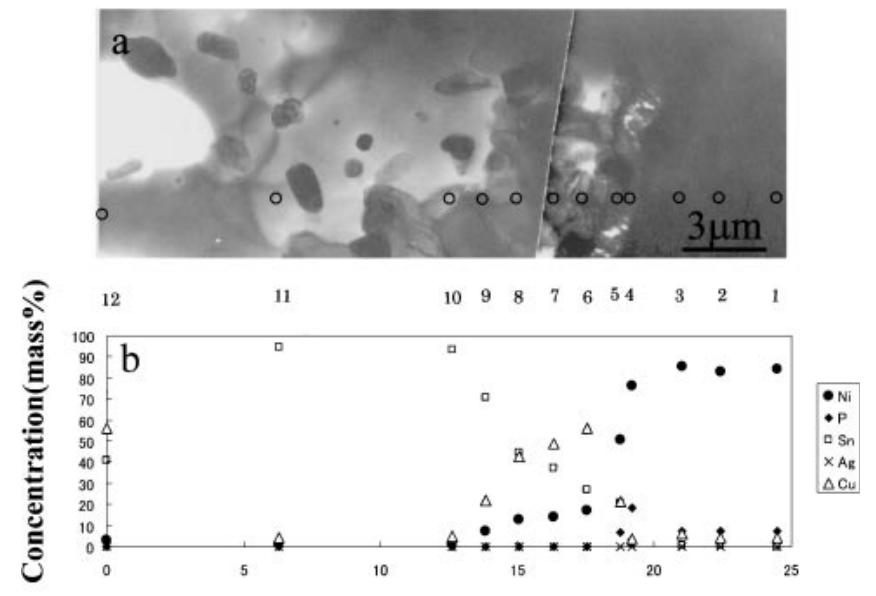

Distance, $d / \mu m$

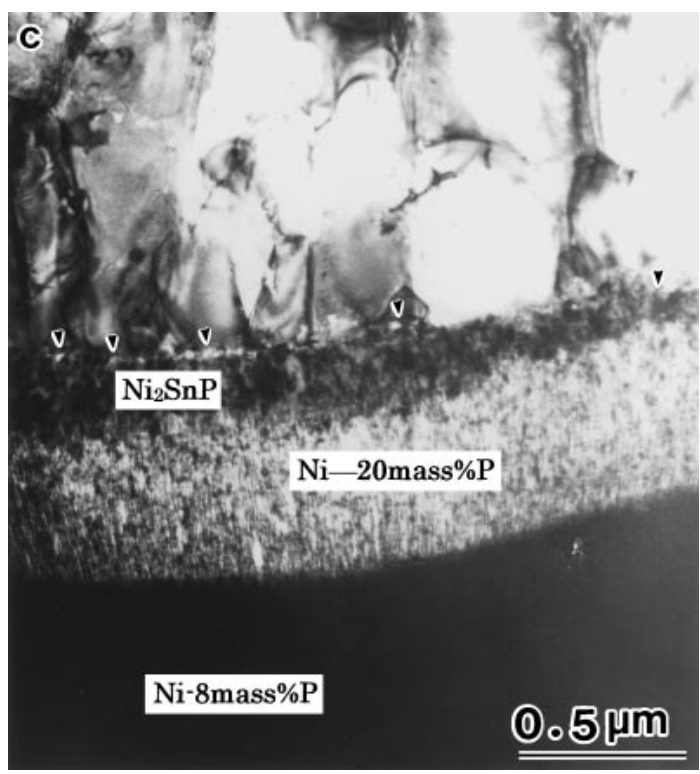

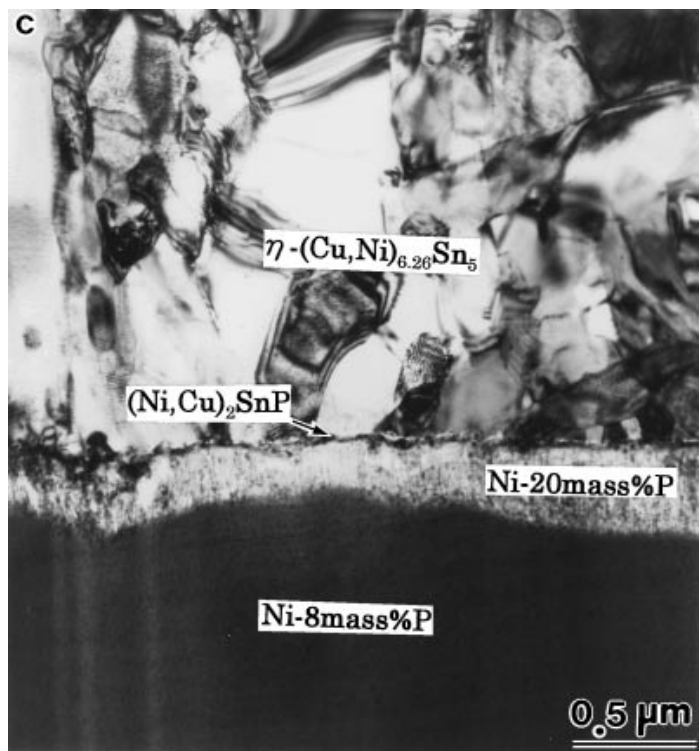

Fig. 4 (a) Low-magnification TEM of a joint between $\mathrm{Sn}-\mathrm{Ag}-\mathrm{Cu}$ solder and Ni-P UBM. (b) Concentration profiles of $\mathrm{Sn}, \mathrm{Ag}$, Cu, Ni and P. (c) High-magnification TEM of the joint.

voids was observed in $\mathrm{Ni}-20$ mass $\% \mathrm{P}$ and $\mathrm{Ni}-\mathrm{Sn}-\mathrm{Cu}-\mathrm{P}$.

\subsubsection{As-joined structure ( $\mathrm{Sn}-\mathrm{Ag}-\mathrm{Cu}-\mathrm{Bi} / \mathrm{Ni}-\mathrm{P}$ )}

Figures 5(a) and (b) shows a solder joint of $\mathrm{Sn}-\mathrm{Ag}-\mathrm{Cu}-\mathrm{Bi} /$ $\mathrm{Ni}-\mathrm{P}$, at a low magnification, and concentration profiles of $\mathrm{P}$, $\mathrm{Ni}, \mathrm{Cu}, \mathrm{Ag}, \mathrm{Bi}$ and $\mathrm{Sn}$, obtained at points $1-16$ by EDX analysis, across the joint, respectively. Figure 5(c) shows the concentration profile of $\mathrm{Bi}$ in more detail. Figure 5(d) shows the joint at a higher magnification. Setting aside the distribution of $\mathrm{Bi}, \mathrm{Ni}-8$ mass $\% \mathrm{P}$ (points 1 and 2), Ni20 mass\% $\mathrm{P}$ (point 3), Ni-Sn-Cu-P (point 4), Ni-Sn-Cu (points 5-8), $\mathrm{Sn}$ (points 9-13 and 15) and $\mathrm{Cu}-\mathrm{Sn}$ (points 14 and 16) were identified. In $\mathrm{Ni}-\mathrm{Sn}-\mathrm{Cu}$, the concentration of $\mathrm{Sn}$ at points 5, 6 and 7 is clearly lower than that at point 8 . This suggests strongly that the phase present at points 5,6 and 7 is different from that at point 8 . Thus, the former will be called $\mathrm{Ni}-\mathrm{Sn}-\mathrm{Cu}(\mathrm{Sn}$ poor) and the latter $\mathrm{Ni}-\mathrm{Sn}-\mathrm{Cu}(\mathrm{Sn}$ rich) hereafter.

Bi exists mostly in Sn (points 9-13 and 15), and virtually does not exist in $\mathrm{Cu}-\mathrm{Sn}$ (points 14 and 16) and $\mathrm{Ni}-\mathrm{P}$ (points 1-4). Furthermore Bi concentration in $\mathrm{Ni}-\mathrm{Sn}-\mathrm{Cu}$ (points 58 ) is quite low. Again, a high density of columnar and spherical voids are observed in Ni-20 mass $\% \mathrm{P}$ and $\mathrm{Ni}-\mathrm{Sn}-$ $\mathrm{Cu}-\mathrm{P}$.

\subsubsection{Microstructure after thermal cycling}

Figures 6(a) and (b) shows microstructures of $\mathrm{Sn}-\mathrm{Ag}-\mathrm{Cu}-$ $\mathrm{Bi}$ solder joints after 20 and 250 cycles in a temperature range between $253 \mathrm{~K}$ and $453 \mathrm{~K}$. Ni-Cu-Sn-P exists just above Ni20 mass \% P layer in a way similar to the as-joined state, but, $\mathrm{Ni}-20$ mass \% P layer is much thinner. This is especially true for the case of 250 cycles. Figure 7 shows concentration 

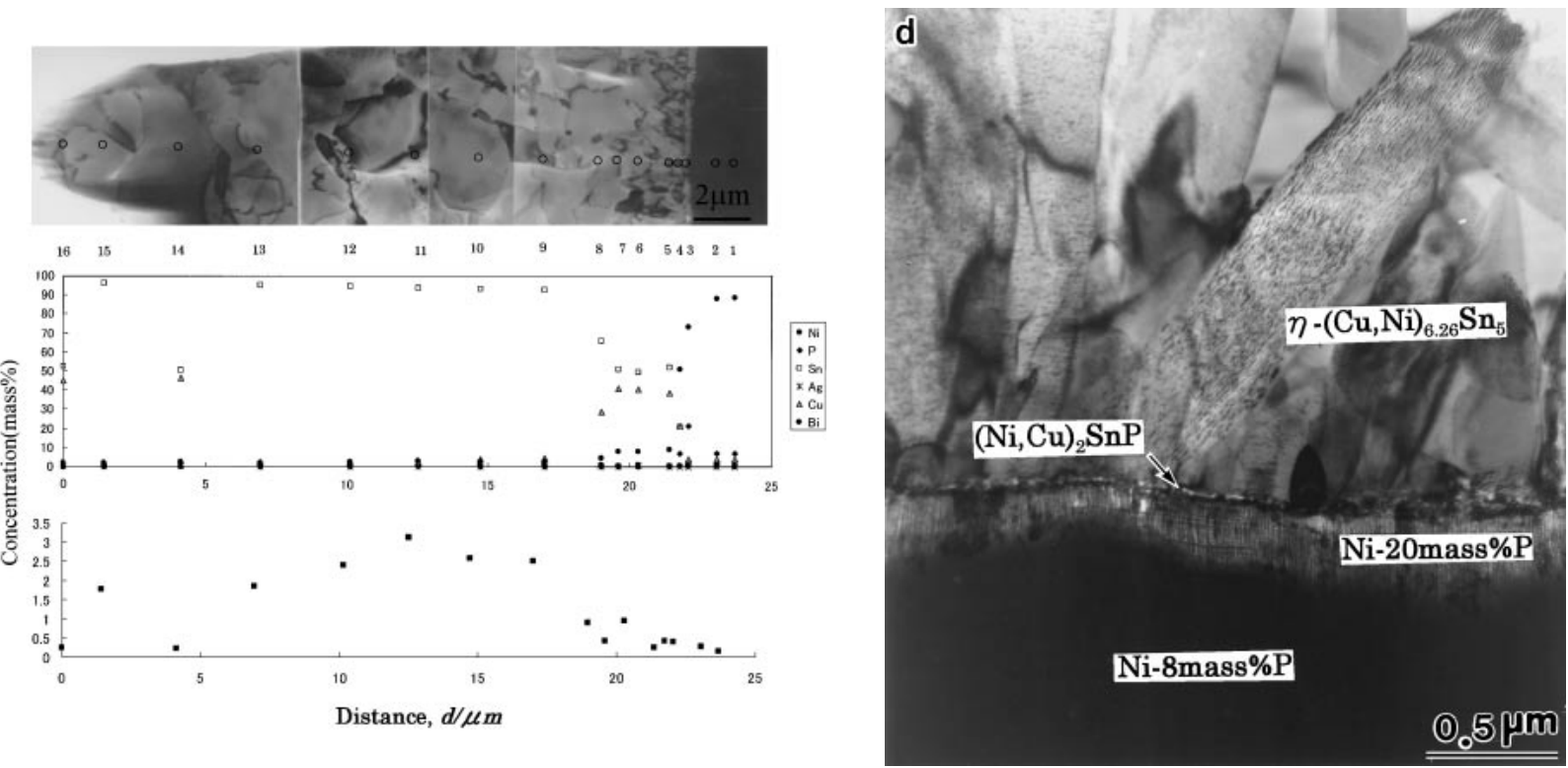

Fig. 5 (a) Low-magnification TEM of a joint between $\mathrm{Sn}-\mathrm{Ag}-\mathrm{Cu}-\mathrm{Bi}$ solder and $\mathrm{Ni}-\mathrm{P}$ UBM. (b) Concentration profiles of $\mathrm{Sn}, \mathrm{Ag}, \mathrm{Cu}, \mathrm{Ni}$, $\mathrm{Bi}$ and P. (c) Concentration profile of Bi expressed in more detail. (d) High-magnification TEM of the joint between $\mathrm{Sn}-\mathrm{Ag}-\mathrm{Cu}-\mathrm{Bi}$ solder and Ni-P UBM.

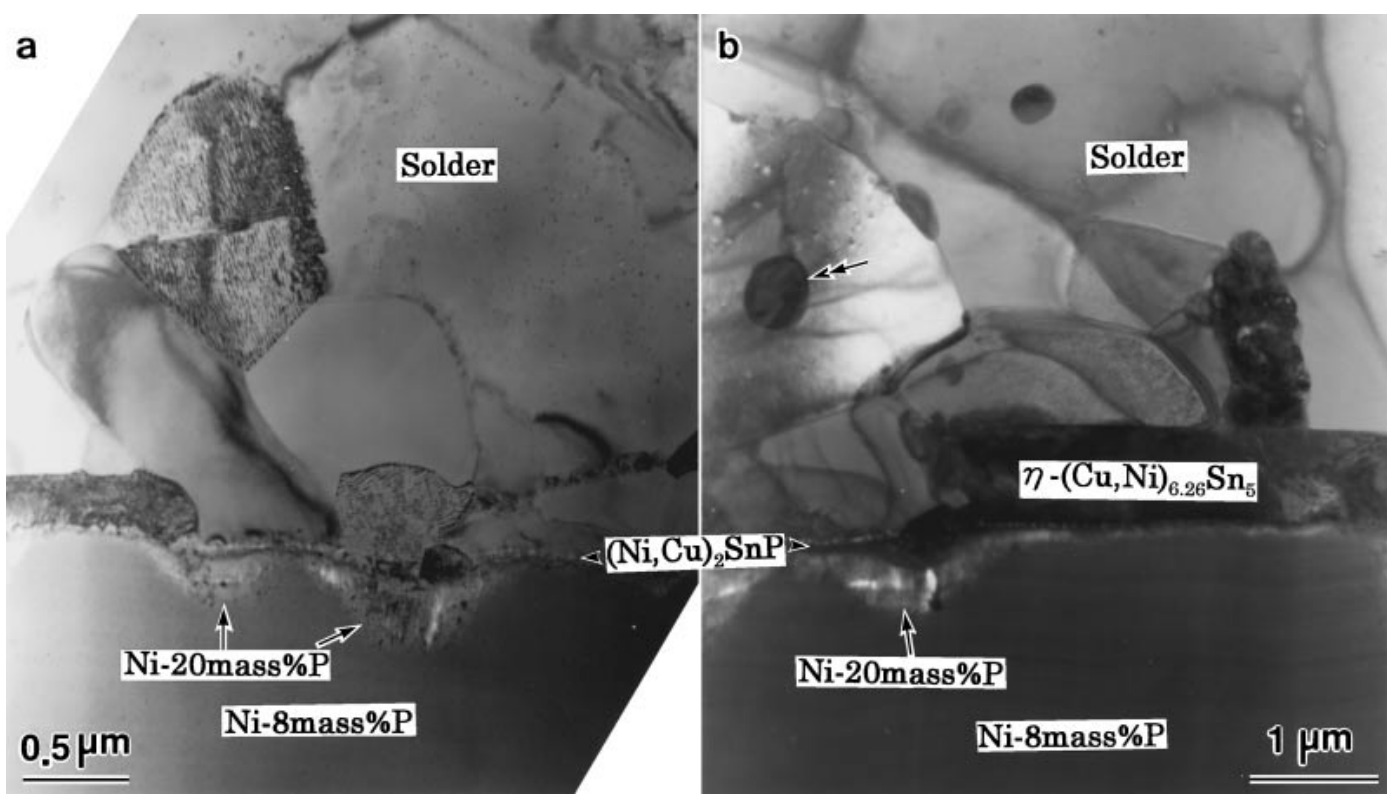

Fig. 6 Microstructure of a joint subjected to thermal cycling up to 20 cycles (a) and 250 cycles (b).

profiles obtained after 250 cycles. Again, neglecting $\mathrm{Bi}, \mathrm{Ni}-$ 8 mass $\% \mathrm{P}$ (point 1), Ni-20 mass $\% \mathrm{P}$ (point 2), Ni-Sn-Cu (Snpoor) (points 3-5), Ni-Sn-Cu (Sn-rich) (point 6), Sn (points 7-8, 10, 11) and Ag-Sn (point 9) were identified.

\subsubsection{Summary of microstructure and EDX analyses}

The aforementioned results may be summarized as follows:

1) $\mathrm{Sn}-\mathrm{Ag} / \mathrm{Ni}-\mathrm{P}$ joint:

There exist 3 layers between a Ni-8 mass\%P UBM and a $\mathrm{Sn}-\mathrm{Ag}$ solder in the following sequence, i.e., (Ni-8 mass\% $\mathrm{P}$ $\mathrm{UBM}) / \mathrm{Ni}-20$ mass $\% \mathrm{P} / \mathrm{Ni}-\mathrm{Sn}-\mathrm{P} / \mathrm{Ni}-\mathrm{Sn} /(\mathrm{Sn}-\mathrm{Ag}$ solder$) . \quad \mathrm{In}-$ side the $\mathrm{Sn}-\mathrm{Ag}$ solder, Ag-Sn islands are distributed. The constitution of the solder joint is essentially similar to that of $\mathrm{Pb}-\mathrm{Sn}$ eutectic solder except that $\mathrm{Pb}$ in the $\mathrm{Pb}-\mathrm{Sn}$ solder is replaced with $\mathrm{Ag}-\mathrm{Sn}$ islands in the $\mathrm{Sn}-\mathrm{Ag}$ solder.

2) $\mathrm{Sn}-\mathrm{Ag}-\mathrm{Cu}-(\mathrm{Bi}) / \mathrm{Ni}-\mathrm{P}$ joint

There exist 4 layers between a Ni-8 mass\% $\mathrm{P}$ UBM and $\mathrm{Sn}-\mathrm{Ag}-\mathrm{Cu}-(\mathrm{Bi})$ solders in the following sequence, i.e., (Ni8 mass $\% \mathrm{P}$ UBM)/Ni-20 mass\%P/Ni-Cu-Sn-P/Sn-poor $\mathrm{Cu}-$ $\mathrm{Ni}-\mathrm{Sn} / \mathrm{Sn}$-rich $\mathrm{Cu}-\mathrm{Ni}-\mathrm{Sn} /(\mathrm{Sn}-\mathrm{Ag}-\mathrm{Cu}-(\mathrm{Bi})$ solder $)$. Inside the solder, $\mathrm{Ag}-\mathrm{Sn}$ and $\mathrm{Cu}-\mathrm{Sn}$ islands are distributed.

Bi was detected in $\mathrm{Sn}$, which was the main component of the solders, and virtually not detected in $\mathrm{Cu}-\mathrm{Sn}$ nor $\mathrm{Ag}-\mathrm{Sn}$ islands, which were the counterparts of the eutectic structures of the solders. Furthermore, Bi concentrations in reaction products such as $\mathrm{Ni}-\mathrm{Sn}-\mathrm{Cu}$ and in Ni-P layers are quite low. 

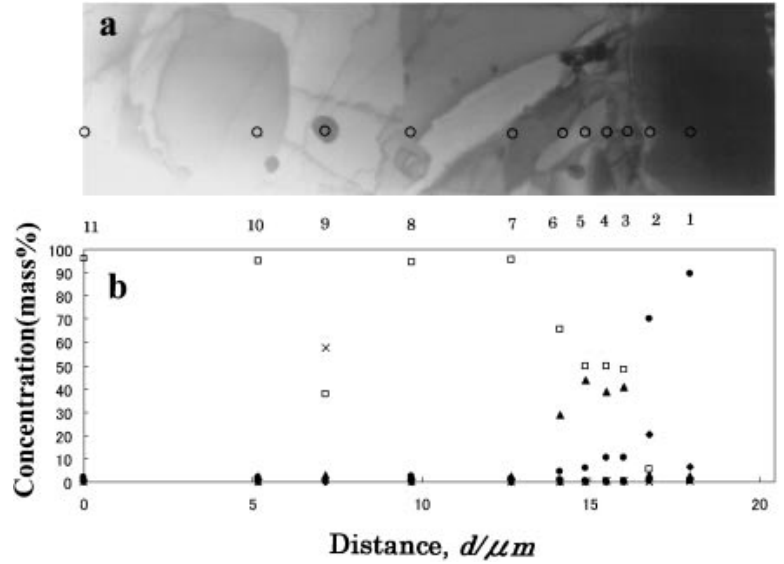

Fig. 7 (a) Low-magnification TEM of a joint between $\mathrm{Sn}-\mathrm{Ag}-\mathrm{Cu}-\mathrm{Bi}$ solder and Ni-P UBM which was subjected to thermal cycling up to 250 cycles. (b) Concentration profiles of $\mathrm{Sn}, \mathrm{Ag}, \mathrm{Cu}, \mathrm{Ni}, \mathrm{Bi}$ and $\mathrm{P}$.

\subsection{Electron diffraction \\ 3.2.1 Ni-8 mass\% $P$}

Figure 8(a) shows a diffraction pattern taken at $\mathrm{Ni}-$ 8 mass $\%$ P layer. The diffraction pattern consists of continuous Debye rings, which are indexed as FCC structure with $a=0.35 \mathrm{~nm}$. Thus, Ni-8 mass\% $\mathrm{P}$ layer is identified as fine polycrystals of $\mathrm{FCC}-\mathrm{Ni}$, in which as large as 8 mass $\% \mathrm{P}$ is solved.

\subsubsection{Ni-20 mass \% $P$}

Figure 8(b) shows a diffraction pattern taken at $\mathrm{Ni}-$ 20 mass\% layer. Debye rings corresponding to FCC-Ni (the first two rings, i.e., $\{111\}$ and $\{200\}$ rings are superimposed in Fig. 8(b)) and diffraction network corresponding to $\mathrm{Ni}_{3} \mathrm{P}$ are evident. The key diagrams are shown in Fig. 8(c).

\subsubsection{Ni-Cu-Sn-P layer}

Figures 9(a) and (b) shows a diffraction pattern taken at $\mathrm{Ni}-\mathrm{Cu}-\mathrm{Sn}-\mathrm{P}$ layer and the key diagram, respectively. The

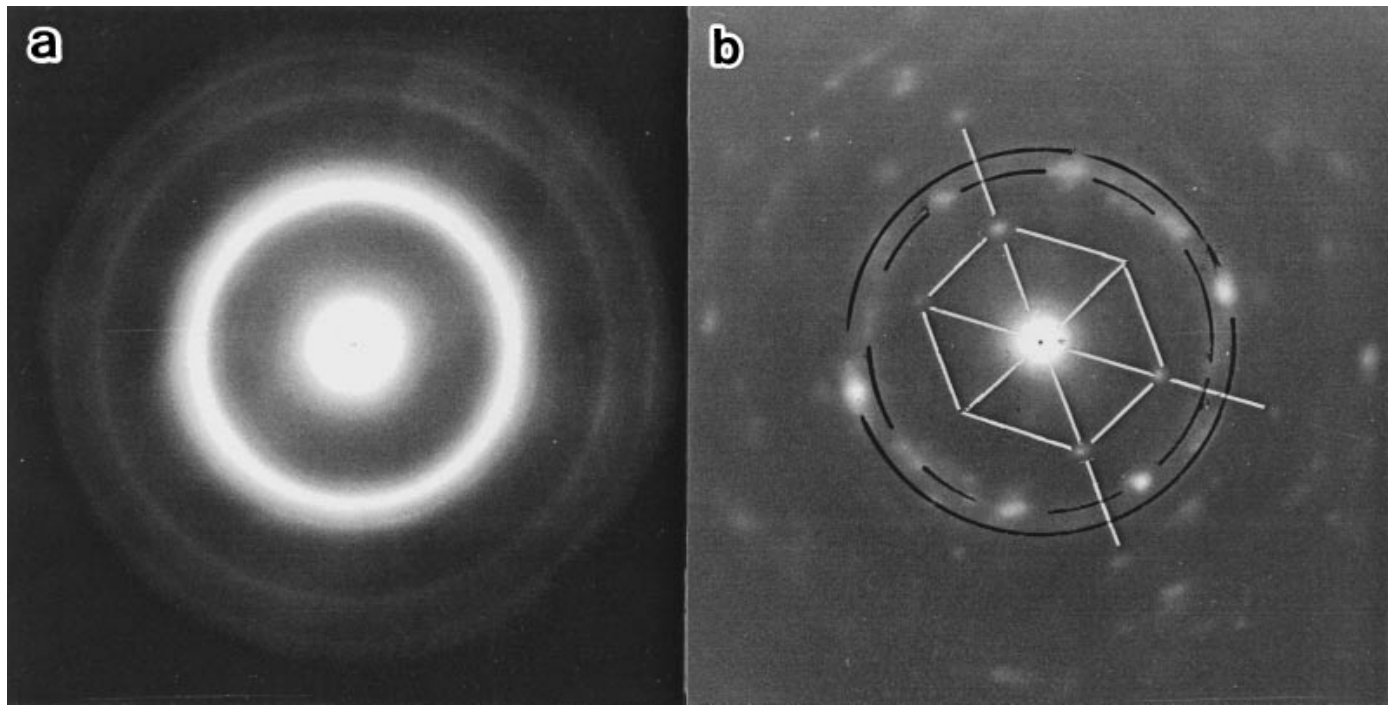

(c)

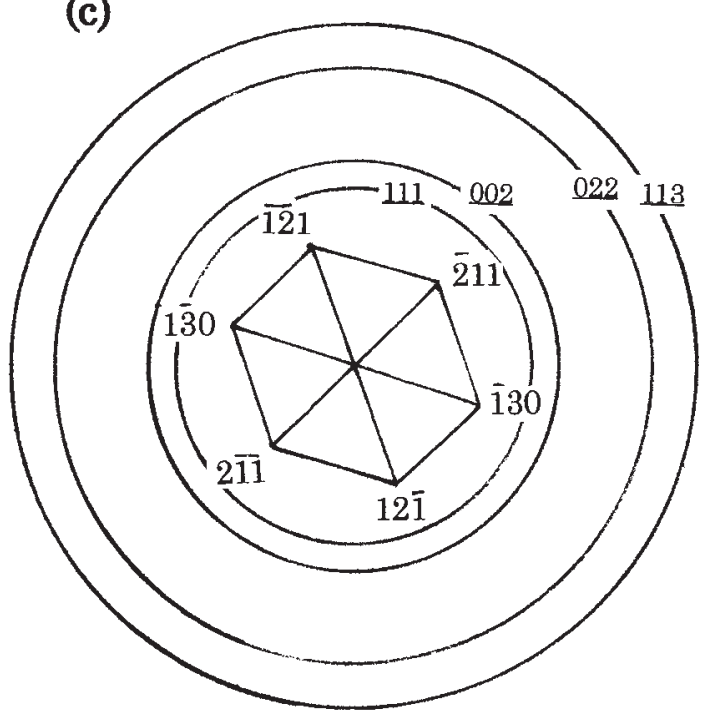

$\mathrm{B}=315$

Fig. 8 (a) Diffraction pattern obtained from the substrate Ni-8 mass\%P UBM. (b) Diffraction pattern obtained from P-enriched (or Nidenuded) Ni-P (Ni-20 mass\% $\%$ ) layer. Diffraction spots from $\mathrm{Ni}_{3} \mathrm{P}$ are indicated by a network. Two circles correspond to Debye rings of $\{111\}$ and $\{200\}$ of $\mathrm{Ni}$. (c) Key diagram to the spots of $\mathrm{Ni}_{3} \mathrm{P}$. Circles indicate Debye rings of Ni, the indices of which are underlined. 

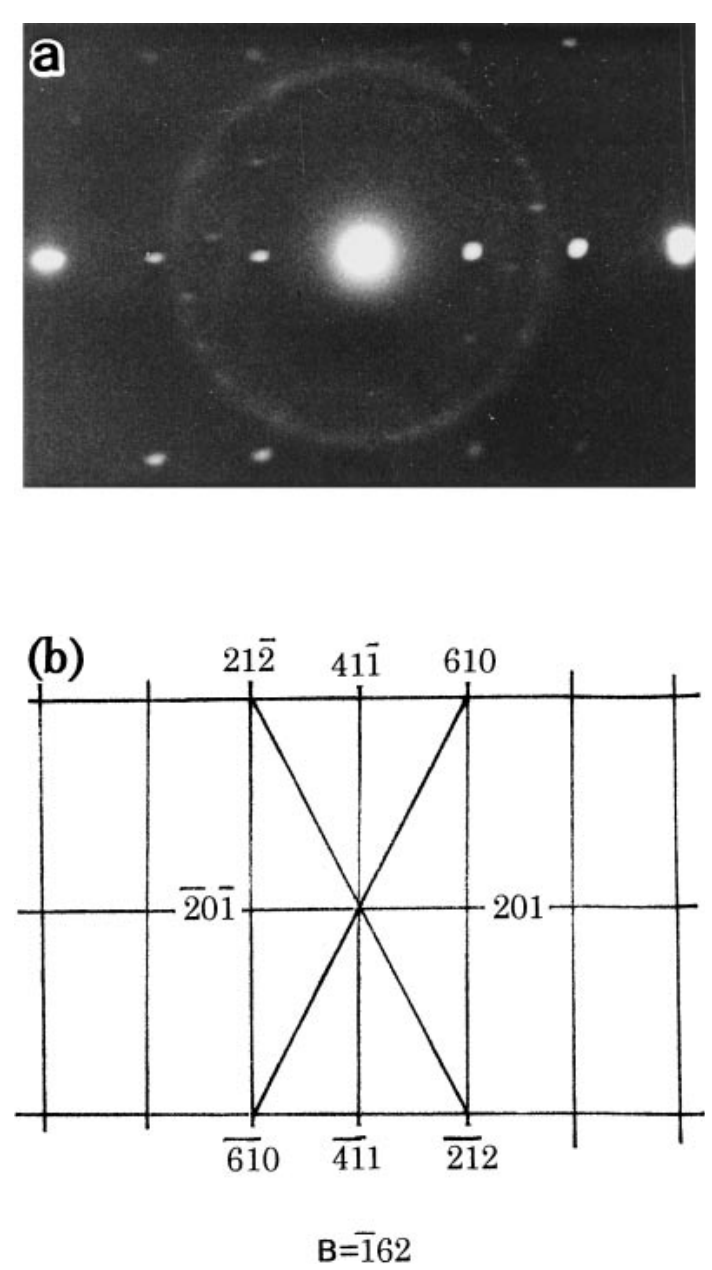

Fig. 9 (a) Diffraction pattern from $\mathrm{Ni}-\mathrm{Cu}-\mathrm{Sn}-\mathrm{P}$ phase. (b) Key diagram to (a).

structure of this layer is identified as $\mathrm{Ni}_{2} \mathrm{SnP}$. However, EDX analysis indicates that this layer contains a large amount of $\mathrm{Cu}$, so that it is concluded that this layer is $(\mathrm{Ni}, \mathrm{Cu})_{2} \mathrm{SnP}$, where part of $\mathrm{Ni}$ is substituted by $\mathrm{Cu}$.

\subsection{4 $\mathrm{Cu}-\mathrm{Ni}-\mathrm{Sn}$ (Sn-poor) layer}

Figures 10(a)-(f) shows diffraction patterns taken at $\mathrm{Cu}-$ $\mathrm{Ni}-\mathrm{Sn}$ (Sn-poor) layer. Figure 10(g) shows relationship between the incident electron beam $\boldsymbol{B}$, with which Figures 10(a)-(f) were taken, and the standard stereo projection. As can be seen from the key diagrams shown in Figures 10( $\left.a^{\prime}\right)$ $\left(\mathrm{f}^{\prime}\right)$, this layer is identified as either $\eta-\mathrm{Cu}_{6} \mathrm{Sn}_{5}$ or $\mathrm{Ni}_{3} \mathrm{Sn}_{2}$. Both $\eta-\mathrm{Cu}_{6} \mathrm{Sn}_{5}$ and $\mathrm{Ni}_{3} \mathrm{Sn}_{2}$ have the space groups of $P 63 / m m c$ and their lattice parameters are very similar ( $c f$. Table 2); it is impossible to distinguish between them from their electron diffraction patterns alone. However, since EDX analysis shows that the layer is much richer in $\mathrm{Cu}$ than $\mathrm{Ni}$, it is reasonable to conclude that this layer is $\eta-(\mathrm{Cu}, \mathrm{Ni})_{6} \mathrm{Sn}_{5}$, where $\mathrm{Ni}$ is substituted partly at the $\mathrm{Cu}$ sites. Furthermore, the diffraction patterns shown in Figs. 10(a)-(f) do not show any superlattice spots. Thus, $\eta-(\mathrm{Cu}, \mathrm{Ni})_{6} \mathrm{Sn}_{5}$, which is a high temperature phase, must have been frozen at room temperature.

\subsection{5 $\mathrm{Cu}-\mathrm{Ni}-\mathrm{Sn}$ (Sn-rich) layer}

Between $\mathrm{Cu}-\mathrm{Ni}-\mathrm{Sn}$ (Sn-poor) layer $\left(\eta-(\mathrm{Cu}, \mathrm{Ni})_{6} \mathrm{Sn}_{5}\right)$ and the solder, $\mathrm{Cu}-\mathrm{Ni}-\mathrm{Sn}$ (Sn-rich) layer, the Sn content of which is higher than that of $\eta-(\mathrm{Cu}, \mathrm{Ni})_{6} \mathrm{Sn}_{5}$ phase, is formed. Figures 11(a) and (b) shows diffraction patterns taken along two different orientations of the incident electron beam $\boldsymbol{B}$. Figures $11\left(\mathrm{a}^{\prime}\right)$ and $\left(\mathrm{b}^{\prime}\right)$ shows the key diagrams of Figs. 11(a) and (b), and the structure of $\mathrm{Cu}-\mathrm{Ni}-\mathrm{Sn}$ (Sn-rich) is identified to be the same as $\mathrm{Ni}_{48} \mathrm{Sn}_{52}$. Since $\mathrm{Cu}-\mathrm{Ni}-\mathrm{Sn}$ (Snrich) layer contains a large amount of $\mathrm{Cu}$, it is concluded that this phase is $(\mathrm{Ni}, \mathrm{Cu})_{48} \mathrm{Sn}_{52}$.

\subsubsection{Ag-Sn island}

Inside the matrices of all the solders studied, islands consisting of $\mathrm{Ag}$ and $\mathrm{Sn}$ are distributed (for example point 8 in Fig. 3(a) and 9 in Fig. 7(a)). Figure 12 shows such an island of $\mathrm{Ag}-\mathrm{Sn}$ imaged at a higher magnification in the dark field mode. Figures 13(a) and (b) shows two examples of diffraction pattern, the key diagrams being shown in Figs. 13( $\left.\mathrm{a}^{\prime}\right)$ and $\left(\mathrm{b}^{\prime}\right)$. This phase is identified as $\mathrm{Ag}_{3} \mathrm{Sn}$. From the diffraction patterns two orientation relationships are established as follows:

$$
\begin{aligned}
& (202) \mathrm{Ag}_{3} \mathrm{Sn} \|(\overline{2} \overline{1} \overline{1}) \beta-\mathrm{Sn} \\
& {[\overline{1} \overline{2} 1] \mathrm{Ag}_{3} \mathrm{Sn} \|[10 \overline{2}] \beta-\mathrm{Sn}}
\end{aligned}
$$

and

$$
\begin{aligned}
& (112) \mathrm{Ag}_{3} \mathrm{Sn} \|(\overline{2} \overline{1} \overline{1}) \beta-\mathrm{Sn} \\
& {[\overline{1} 3 \overline{1}] \mathrm{Ag}_{3} \mathrm{Sn} \|\left[{ }_{10} \overline{2}\right] \beta-\mathrm{Sn}}
\end{aligned}
$$

\subsection{7 $\mathrm{Cu}-\mathrm{Sn}$ island}

In the matrices of the $\mathrm{Cu}$-containing solders, regions consisting of $\mathrm{Cu}$ and $\mathrm{Sn}$ are observed. Diffraction patterns (not shown) taken in these regions are very similar to those from $\mathrm{Cu}-\mathrm{Ni}-\mathrm{Sn}$ (Sn-poor) layer, i.e., $\eta-(\mathrm{Cu}, \mathrm{Ni})_{6} \mathrm{Sn}_{5}$ phase. However, this $\mathrm{Cu}-\mathrm{Sn}$ region is different from $\mathrm{Cu}-\mathrm{Ni}-\mathrm{Sn}(\mathrm{Sn}-$ poor) layer in that $\mathrm{Cu}-\mathrm{Sn}$ region is observed well far away from the solder joint and that $\mathrm{Ni}$ is not contained at all. Thus, it is concluded that the $\mathrm{Cu}-\mathrm{Sn}$ region is $\eta-\mathrm{Cu}_{6} \mathrm{Sn}_{5}$ phase, and not $\eta-\left(\mathrm{Cu}, \mathrm{Ni}_{6} \mathrm{Sn}_{5}\right.$ phase. It is formed as the primary phase when the solder freezes.

\subsubsection{Summary of the solder joints}

Figures 14(a) and (b) shows schematically the joints to UBM of $\mathrm{Sn}-\mathrm{Ag}$ solder and $\mathrm{Sn}-\mathrm{Ag}-\mathrm{Cu}-(\mathrm{Bi})$ solder, respectively. The microstructure of the $\mathrm{Sn}-\mathrm{Ag} / \mathrm{Ni}-\mathrm{P}$ joint (Fig. 14(a)) is essentially similar to that of $\mathrm{Pb}-\mathrm{Sn}$ eutectic solder, except that $\mathrm{Pb}$ is replaced by $\mathrm{Ag}_{3} \mathrm{Sn}$. Neither $\mathrm{Pb}$ nor $\mathrm{Ag}$ participates in the reactions during soldering; only $\mathrm{Sn}$ does. By contrast, in the case of $\mathrm{Cu}$-containing solders, i.e., $\mathrm{Sn}-$ $\mathrm{Ag}-\mathrm{Cu}-(\mathrm{Bi}) / \mathrm{Ni}-\mathrm{P}$ (Fig. 14(b)), Cu participates in the reactions during soldering. As a result, intermetallic compounds, formed as the reaction products, are different from those formed in the cases of $\mathrm{Sn}-\mathrm{Ag}$ and $\mathrm{Pb}-\mathrm{Sn}$ solders.

However, from the viewpoint of diffusion of $\mathrm{Ni}$ and $\mathrm{P}$ from the $\mathrm{Ni}-\mathrm{P}$ substrate, the situations in $\mathrm{Cu}$-free and $\mathrm{Cu}$-containing solders are similar. Matsuki et al. ${ }^{4)}$ have discussed formation mechanism of voids formed in Ni-20 mass $\% \mathrm{P}$ and $\mathrm{Ni}-\mathrm{Sn}-\mathrm{P}$, which corresponds to $(\mathrm{Ni}, \mathrm{Cu})-\mathrm{Sn}-\mathrm{P}$ in the case of $\mathrm{Cu}$-containing solder, based on in-situ observation of motion of individual interfaces in a joint. They concluded that diffusion of $\mathrm{Sn}$ in $\mathrm{Ni}_{2} \mathrm{SnP}$ is sluggish, while Ni can diffuse easily across $\mathrm{Ni}_{2} \mathrm{SnP}$. In order for $\mathrm{Ni}-\mathrm{Sn}$ to keep growing, $\mathrm{Ni}$ must be supplied all the way from the electroless $\mathrm{Ni}-$ 8 mass \%-P. Thus, the content of $\mathrm{Ni}$ in the electroless $\mathrm{Ni}-$ 8 mass\%P keeps decreasing. If the supply of $\mathrm{Ni}$ from the 


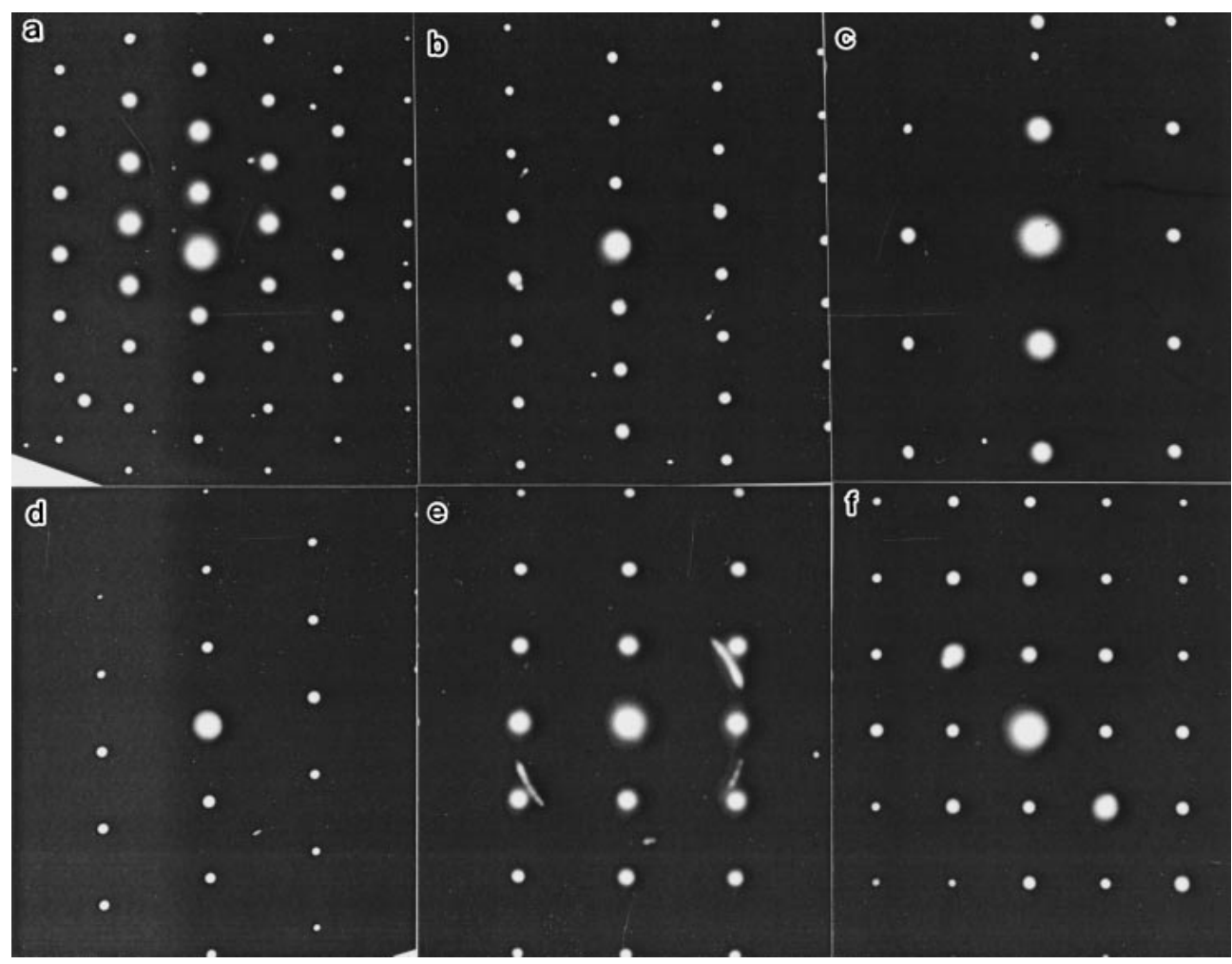

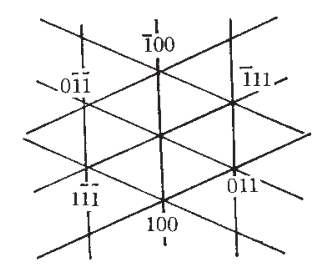

(a) $\mathrm{B}=\mathbf{0} \overline{1}$

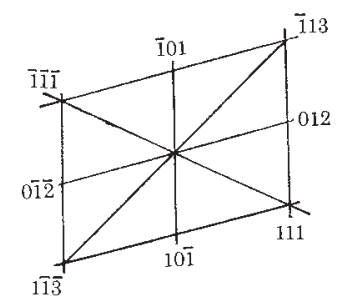

(d) $\mathrm{B}=1 \overline{2} 1$

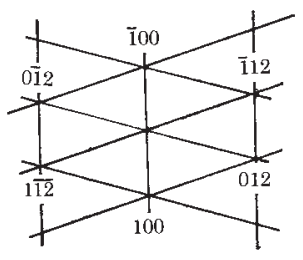

(6) $\mathrm{B}=0 \overline{2} 1$

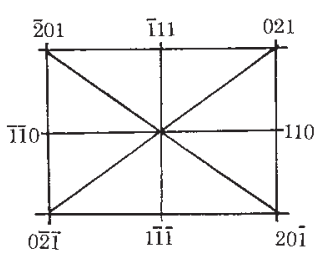

(é) $\mathrm{B}=1 \overline{1} 2$

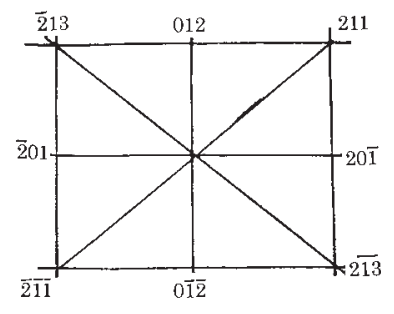

(c) $\mathrm{B}=1 \overline{4} 2$

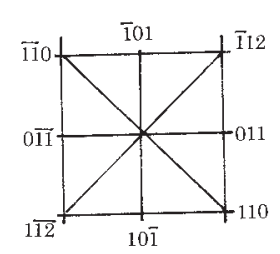

(f) $\mathrm{B}=1 \overline{1} 1$

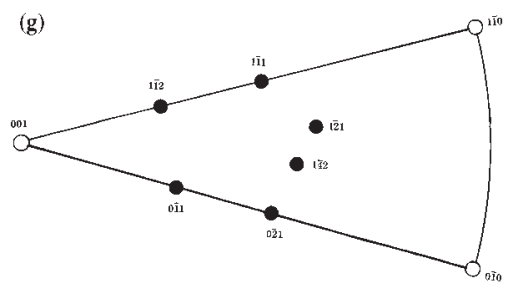

Fig. 10 (a)-(f) Diffraction patterns from (Ni, Cu)-Sn (Sn poor) phase. (a')-(f') Key diagrams to (a)-(f). (g) Relationship of the zone axes along which (a)-(f) were taken. 

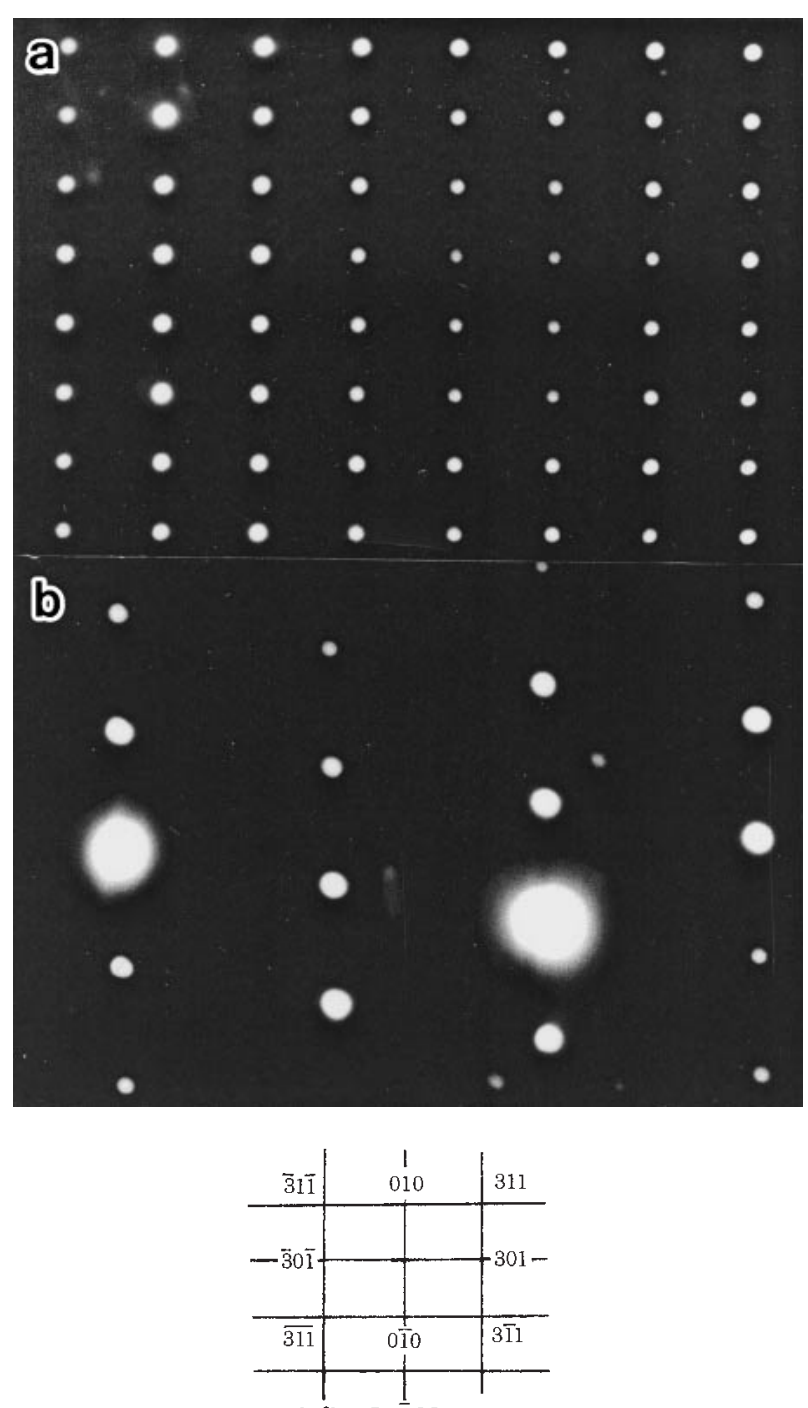

(a') $B=103$

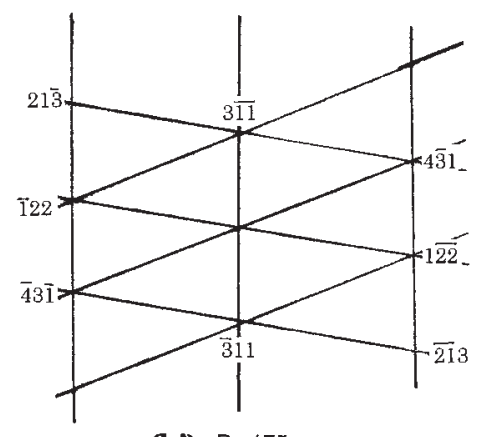

(b’) $B=475$

Fig. 11 (a), (b) Diffraction patterns from $(\mathrm{Ni}, \mathrm{Cu})-\mathrm{Sn}(\mathrm{Sn}$ rich) phase. $\left(a^{\prime}\right)$ and $\left(b^{\prime}\right)$ are key diagrams to (a) and (b)

underlying $\mathrm{Ni}-8$ mass\% $\mathrm{P}$ is not sufficient, voids may be formed and grow along the diffusion path of $\mathrm{Ni}$ in $\mathrm{Ni}-$ 20 mass $\%$ P, leading to formation of columnar voids. The formation of spherical voids in $\mathrm{Ni}_{2} \mathrm{SnP}$ can be explained by assuming that diffusion of $\mathrm{Ni}$ in $\mathrm{Ni}_{2} \mathrm{SnP}$ is slower than in $\mathrm{Ni}-$ $\mathrm{Sn}$. This difference in diffusivity of $\mathrm{Ni}$ gives rise to imbalance of supply of $\mathrm{Ni}$ at the $\mathrm{Ni}_{3} \mathrm{Sn}_{4} / \mathrm{Ni}_{2} \mathrm{SnP}$ interface, which leads to formation of spherical voids near the $\mathrm{Ni}_{3} \mathrm{Sn}_{4} / \mathrm{Ni}_{2} \mathrm{SnP}$ interface in $\mathrm{Ni}_{2} \mathrm{SnP}$. Both of these two types of void are

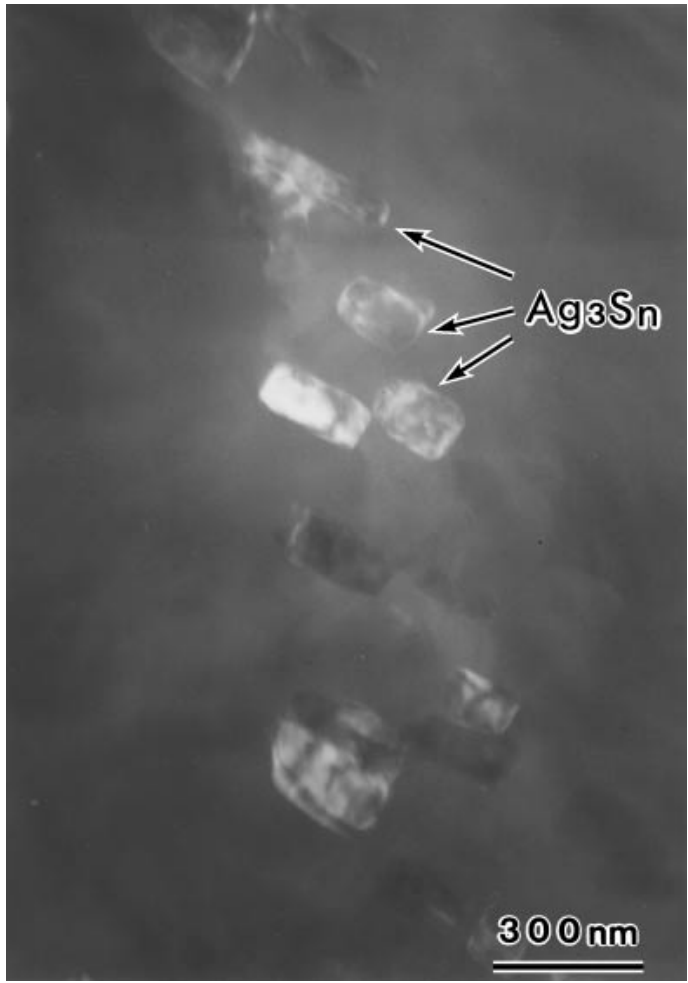

Fig. 12 Dark-field micrograph at higher magnification of $\mathrm{Ag}_{3} \mathrm{Sn}$ phases dispersed in the matrix of $\mathrm{Sn}$.
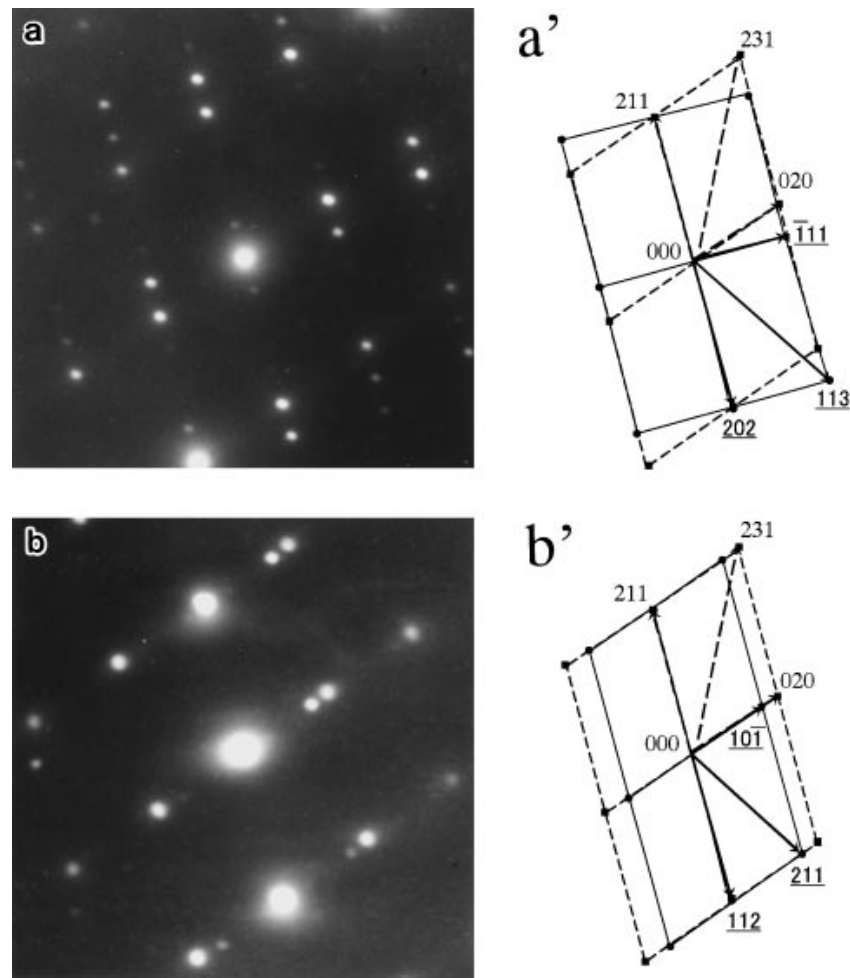

Fig. 13 (a) and (b) Diffraction patterns from $\operatorname{Ag}_{3} \mathrm{Sn},\left(\mathrm{a}^{\prime}\right)$ and $\left(\mathrm{b}^{\prime}\right)$ Key diagrams to (a) and (b). Indeces of $\mathrm{Ag}_{3} \mathrm{Sn}$ are underlined. Spots denoted by * in (b) are forbidden reflections which appear as a result of the double reflection. Beam direction is normal to the (1) 121$)$ plane for $\mathrm{Ag}_{3} \mathrm{Sn}$ and to the $(10 \overline{2})$ plane for $\mathrm{Sn}$. 


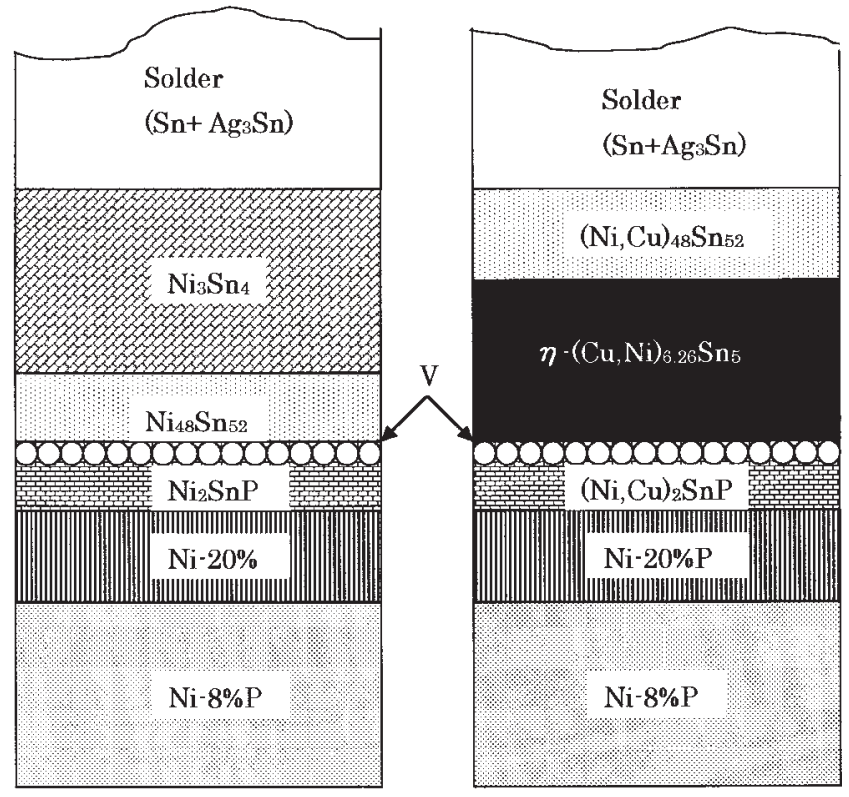

(a)

(b)

Fig. 14 (a) Microstructure of a joint between $\mathrm{Sn}-\mathrm{Ag}$ and $\mathrm{Ni}-8$ mass\% $\mathrm{P}$ UBM. (a) Microstructure of a joint between $\mathrm{Sn}-\mathrm{Ag}-\mathrm{Cu}-(\mathrm{Bi})$ and $\mathrm{Ni}-$ 8 mass $\%$ P UBM.

formed because the diffusion coefficients of the major components, i.e., $\mathrm{Ni}, \mathrm{P}$ and $\mathrm{Sn}$, are not constant.

\subsection{Strength and fracture of the joints}

Figure 15 shows an electron micrograph of a joint of Sn$\mathrm{Ag}-\mathrm{Cu} / \mathrm{Ni}-\mathrm{P}$ fractured by a pull test. It is evident that fracture took place mostly along $(\mathrm{Ni}, \mathrm{Cu})_{2} \mathrm{SnP} / \mathrm{Ni}-20$ mass $\% \mathrm{P}$, and occasionally inside $(\mathrm{Cu}, \mathrm{Ni})_{6} \mathrm{Sn}_{5}$. Thus, it is reasonable to conclude that the columnar voids in the $\mathrm{Ni}-20$ mass\% $\mathrm{P}$ layer degrades the strength of the joint. This is in keeping with the case of $\mathrm{Pb}-\mathrm{Sn} / \mathrm{Ni}-\mathrm{P}$ joint.

Figure 16 shows variation in the pull load as a function of the number of cycle of thermal cycling. The pull load remains

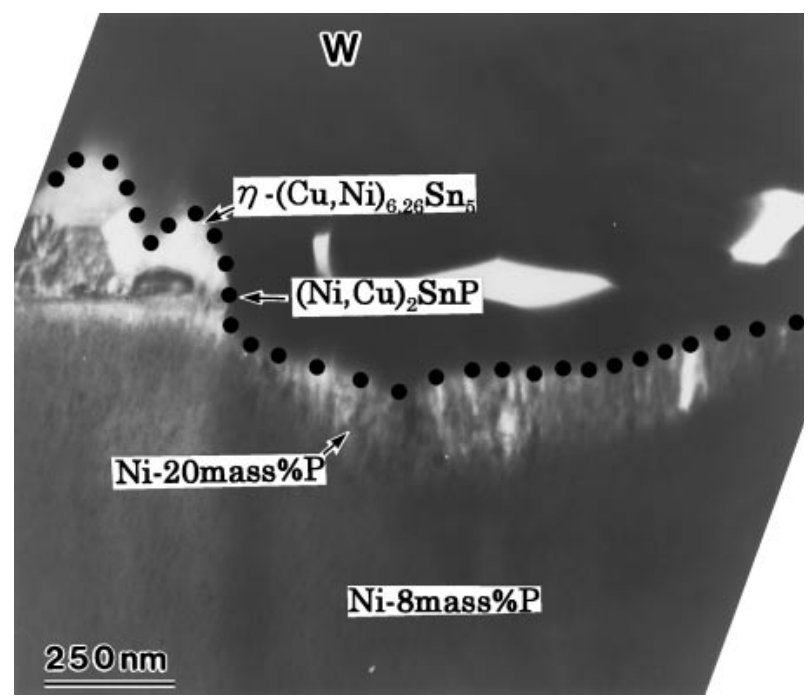

Fig. 15 Cross-sectional TEM of a $\mathrm{Sn}-\mathrm{Ag}-\mathrm{Cu} / \mathrm{Ni}-\mathrm{P}$ joint pulled to fracture. $\mathrm{W}$ denotes a protective layer of tungsten deposited prior to FIB milling and has nothing with structures of the joint.

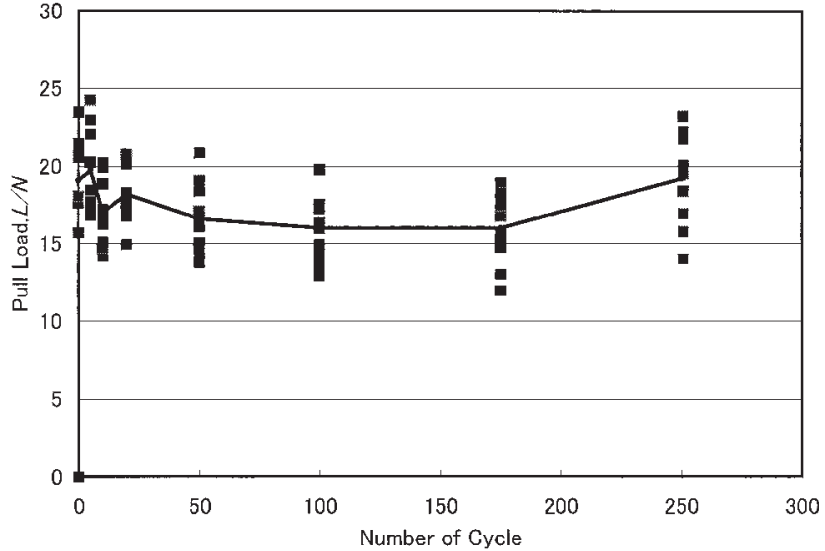

Fig. 16 Variation in the tensile strength of a $\mathrm{Sn}-\mathrm{Ag}-\mathrm{Cu}-\mathrm{Bi} / \mathrm{Ni}-\mathrm{P}$ joint as a function of the number of thermal cycle. The solid line indicates the values averaged over 10 measurements.

virtually unchanged. During thermal cycling the thickness of $\mathrm{Ni}-20$ mass $\% \mathrm{P}$ where a high density of columnar voids exist decreases dramatically. However, surprisingly the pull load remains unchanged. One possible explanation to this is that, during thermal cycling $\eta$ - $(\mathrm{Cu}, \mathrm{Ni})_{6} \mathrm{Sn}_{5}$ intermetallics also coarsen, thus canceling the improvement of the joint strength due to shrinkage of columnar voids.

\section{Summary}

Microstructures of interfaces of joints between Ni8 mass $\% \mathrm{P} \mathrm{UBM}$ and three different $\mathrm{Pb}$-free solders, i.e., $\mathrm{Sn}-\mathrm{Ag}, \mathrm{Sn}-\mathrm{Ag}-\mathrm{Cu}$ and $\mathrm{Sn}-\mathrm{Ag}-\mathrm{Cu}-\mathrm{Bi}$ were observed by TEM. The results obtained are as follows:

(1) In $\mathrm{Sn}-\mathrm{Ag} / \mathrm{Ni}-\mathrm{P}$ joint, 3 layers are formed at the joint in the following sequence, i.e., $(\mathrm{Ni}-8$ mass $\% \mathrm{P} \mathrm{UBM}) / \mathrm{Ni}-$ 20 mass $\% \mathrm{P} / \mathrm{Ni}_{2} \mathrm{SnP} / \mathrm{Ni}-\mathrm{Sn} /(\mathrm{Sn}-\mathrm{Ag}$ solder $)$. Inside the $\mathrm{Sn}-\mathrm{Ag}$ solder, $\mathrm{Ag}_{3} \mathrm{Sn}$ islands are distributed. The constitution of the solder joint is essentially similar to that of $\mathrm{Pb}-\mathrm{Sn}$ eutectic solder except that $\mathrm{Pb}$ in the $\mathrm{Pb}-$ $\mathrm{Sn}$ solder is replaced with $\mathrm{Ag}-\mathrm{Sn}$ islands in the $\mathrm{Sn}-\mathrm{Ag}$ solder.

(2) In $\mathrm{Cu}$-containg solders, i.e., $\mathrm{Sn}-\mathrm{Ag}-\mathrm{Cu}-(\mathrm{Bi}), 4$ layers are formed between a Ni-8 mass\% $\mathrm{P}$ UBM and $\mathrm{Sn}-\mathrm{Ag}-$ $\mathrm{Cu}-(\mathrm{Bi})$ solders in the following sequence, i.e., (Ni8 mass $\% \mathrm{P} \quad \mathrm{UBM}) / \mathrm{Ni}-20$ mass $\% \mathrm{P} /(\mathrm{Ni}, \mathrm{Cu})_{2} \mathrm{SnP} / \eta-(\mathrm{Cu}$, $\mathrm{Ni})_{6} \mathrm{Sn}_{5} /(\mathrm{Ni}, \mathrm{Cu})_{2} \mathrm{SnP} /(\mathrm{Sn}-\mathrm{Ag}-\mathrm{Cu}-(\mathrm{Bi})$ solder $)$.

(3) Inside the solder, $\mathrm{Ag}_{3} \mathrm{Sn}$ and $\eta-\mathrm{Cu}_{6} \mathrm{Sn}_{5}$ islands are distributed.

(4) The following orientation relationships between $\mathrm{Ag}_{3} \mathrm{Sn}$ and $\beta$-Sn are established

$$
\begin{aligned}
& (202) \mathrm{Ag}_{3} \mathrm{Sn} \|(\overline{2} \overline{1} \overline{1}) \beta-\mathrm{Sn} \\
& {[\overline{1} \overline{2} 1] \mathrm{Ag}_{3} \mathrm{Sn} \|[10 \overline{2}] \beta-\mathrm{Sn}}
\end{aligned}
$$

and

$$
\begin{aligned}
& \text { (112) } \mathrm{Ag}_{3} \mathrm{Sn} \|(\overline{2} \overline{1} \overline{1}) \beta-\mathrm{Sn} \\
& {[\overline{1} 3 \overline{1}] \mathrm{Ag}_{3} \mathrm{Sn} \|[10 \overline{2}] \beta-\mathrm{Sn}}
\end{aligned}
$$

(5) $\mathrm{Bi}$ is detected in $\mathrm{Sn}$, which is the main component of the solders, and virtually not detected in $\mathrm{Ag}_{3} \mathrm{Sn}$ nor $\eta$ $\mathrm{Cu}_{6} \mathrm{Sn}_{5}$ islands, which are the counterparts of the eutectic structures of the solders. 
(6) $\mathrm{Bi}$ concentration in reaction products and the $\mathrm{Ni}-\mathrm{P}$ layers is quite low.

(7) A high density of columnar voids are formed in $\mathrm{Ni}-$ 20 mass $\% \mathrm{P}$ near the interface with $\mathrm{Ni}_{2} \mathrm{SnP}$ or $(\mathrm{Ni}, \mathrm{Cu})_{2} \mathrm{SnP}$.

(8) A high density of spherical voids are formed in $\mathrm{Ni}_{2} \mathrm{SnP}$ or $(\mathrm{Ni}, \mathrm{Cu})_{2} \mathrm{SnP}$ near the interface with $\mathrm{Ni}-\mathrm{Sn}$ or $\mathrm{Ni}-$ $\mathrm{Cu}-\mathrm{Sn}$ intermetallics.

(9) These voids, especially columnar ones, degrade the strength of the joints.

(10) After thermal cycling between 253 and $453 \mathrm{~K}, \mathrm{Ni}-$ 20 mass \% P layer decreases in thickness substantially.

(11) At the same time $\eta$ - $\left(\mathrm{Cu}, \mathrm{Ni}_{6} \mathrm{Sn}_{5}\right.$ intermetallics also coarsen during thermal cycling, and this may cancel the improvement of the joint strength due to shrinkage of columnar voids.

\section{Acknowledgements}

The authors thank Dr. J. Shah of Bristol University for reading the manuscript. This work was supported by Grantin-Aid for Scientific Research (A) from the Ministry of Education, Culture, Sports, Science and Technology.

\section{REFERENCES}

1) For example, K. Suganuma et al.: Materia Japan 38 (1999) 919-974.

2) J.-H. Lee, D.-J. Pak, J.-N. Heo, Y.-H. Lee, D.-H. Shin and Y.-S. Kim: Scr. Mater. 42 (2000) 827-831.

3) J. W. Jang, P. G. Kim, K. N. Tu, D. R. Frear and R. Thompson: J. Appl. Phys. 85 (1999) 8456-8463.

4) H. Matsuki, H. Ibuka and H. Saka: J. Japan Inst. Metals 64 (2000) 213217.

5) N. Torazawa, S. Arai, K. Shimomura, Y. Takase and H. Saka: J. Japan Inst. Metals 66 (2002) 47-52.

6) H. Matsuki, H. Ibuka and H. Saka: Sci. Technol. Advanced Materi. 3 (2002) 261-270.

7) Y. Kariya, K. Nakamura, Y. Tanaka and M. Otsuka: Proc. 6th Symp. on Microjoining and Assembly Technology in Electronics, (Japan Welding Society, Tokyo 2000) pp. 217-222. 